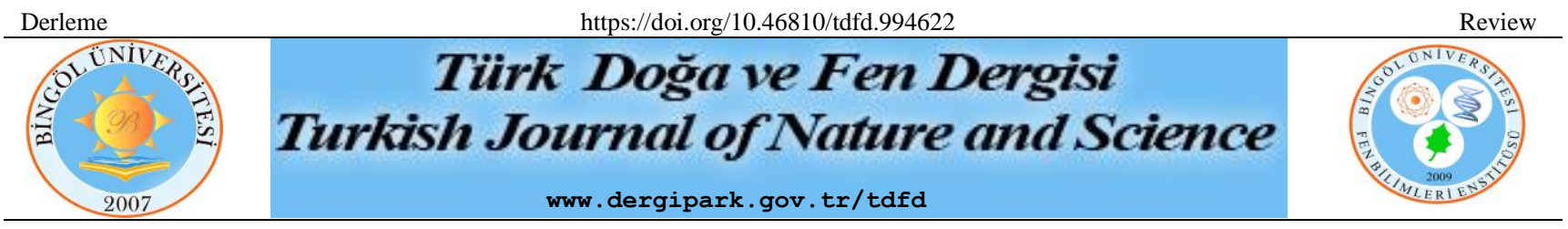

mRNA SARS-CoV2 Specific and Childhood Vaccines against Covid-19 Pandemic

\author{
İdris YAZGAN \\ Kastamonu Üniversitesi, Fen Edebiyat Fakültesi, Biyoloji Bölümü, Kastamonu, Türkiye \\ İdris YAZGAN ORCID No: 0000-0002-0264-1253 \\ *Corresponding author: iyazgan@kastamonu.edu.tr
}

(Alınış: 13.09.2021, Kabul: 11.11.2021, Online Yayınlanma: 31.12.2021)

\begin{abstract}
Keywords SARSCoV2, mRNA vaccines, conventional vaccines, immunity

Abstract: The coronavirus disease 2019 (Covid-19) pandemic has been challenging the entire world since early 2020. Due to the fact that there is no universally available treatment method along with the disease's fast transmission from human to human, specific vaccine development efforts have got a great attention. Particularly mRNA-based severe acute respiratory syndrome coronavirus 2 (SARS$\mathrm{CoV} 2)$ specific vaccines are administrated to individuals worldwide to combat against Covid-19 infection. Even though two dose mRNA vaccination provides immunity against ancestral and aggressive variants of SARS-CoV2 infections, rare detrimental short-time side effects and no-data availability on long-term possible side-effects along with unpredictable vaccination regime bring hesitancy against the vaccines. Besides, the vaccination regime is still under debate among the scientist as that whether pre-infected individuals require further vaccination and what should be the ideal vaccination dose. In addition to mRNA SARS-CoV2 specific vaccines, recent retrospective, theoretical, clinical, and biochemical studies revealed that trained innate immunity and heterologous T-cells and memory B-cells can be strong alternative to combat against SARS-CoV2 pandemic. In this context, conventional childhood vaccines (e.g., BCG and MMR) are proposed as valuable alternative vaccines against the pandemic with known clinical outcomes and effectivity.
\end{abstract}

\title{
Covid-19’a karşı mRNA SARS-CoV2 spesifik ve Çocukluk Dönemi Aşıları
}

\section{Anahtar \\ Kelimeler \\ SARS-CoV2, mRNA aşıları, Klasik aşılar, Bağışıklık}

\begin{abstract}
Öz: 2019 yılı koronavirus hastalığı (Covid-19) pandemisi 2020 yılından beri dünya çapında bir sorun haline gelmiştir. Evrensel olarak kabul edilmiş bir tedavisinin olmayışı ve insandan-insana geçişinin hızlı olması nedeniyle spesifik aşı geliştirme çalışmaları önem kazanmıştır. mRNA-temelli ağır akut solunum yolu yetersizliği sendromu korovirus 2 (SARS-CoV2) aşıları dünya çapında Covid-19'un kontrol altına alınmasına yönelik olarak en yaygın olarak kullanılan aşılardır. Herne kadar iki doz mRNA aşılarının hem atasal hemde mutasyona uğramış agresif SARS-CoV2 viral enfeksiyonlarına karşı yüksek bağışıklık sağlıyor olmalarına karşın, nadir olarak görülen kısa dönem yan etkileri ve uzun dönemli olası yan etkileri hakkında bilgilerin mevcut olmaması nedeniyle aşılara karşı bir tereddüt mevcuttur. Buna ek olarak, aşılama rejimin nasıl olması gerektiği bilimadaları arasında hala tartışma konusudur, örneğin enfeksiyon geçirmiş olan bireyler tekrar aşı olmalı mı ve kaç doz aşı olunması gerekir. mRNA temelli SARS-CoV2 aşılarına alternatif olarak, yeni yapılan retrospektif, teorik, klinik ve biyokimyasal çalışmalar, eğitilmiş doğal bağışıklığın ve heterelog T-hücrelerinin ve hafiza B hücrelerinin SARS-CoV2 pandemisine karşı savaşta önemli bir alternatif olabileceği önerilmiştir. Bu kapsamda, klasik çocukluk dönemi aşılarının (örneğin BCG ve MMR) pandemiye karşı bilinen klinik souçları ve etkinliği nedeniyle önemli alternatif aşılar oldukları görülmektedir.
\end{abstract}

\section{INTRODUCTION}

By December 2019, an unknown pneumonia reported for the $66 \%$ workers of the Huanan Seafood Wholesale Market of Wuhan. By January 2020, the unknown pneumonia spread to different provinces of China, followed by it spread out all over the world including the US, Germany, Korea and Japan. By early February 2020, the virus-infected-population reached to $\sim 30$ thousands confirmed cases with 565 death [1]. Upon characterization of the virus and its global health treating 
position, world health organization (WHO) declared pandemic of severe acute respiratory syndrome coronavirus 2 (SARS-CoV2) on March 12, 2020 [2]. By April 2020, SARS-CoV2 cases were reported for over 200 countries [3]. Based on https://www.worldometers.info/coronavirus/ open tracker source 222,846,841 confirmed cases with 4,602,027 deaths (access data September 8, 2021) were reported world-wide. 35 countries reported over 1 million confirmed cases, where the three highest confirmed cases were from the US, India and Brazil. Even though the major effect of the pandemic is visible for older individuals, younger individuals and children are the invisible victims of the pandemic. Closing down the schools (A Norwegian based study revealed that children under 14-years old do not contribute transmission of SARS-CoV2 infection [4]), delayed childhood vaccination and lack of healthcare services are among the major treats to the younger individuals [5]. Therefore, the devastating effect of the pandemic is beyond the anticipated level. Besides these, the pandemic has caused tremendous waste accumulation including facemasks, and cleaning of the accumulated waste in sea and soil will be challenging as well [6]. So, the pandemic is devastating in all aspects.

Phylogenetic analyses revealed that SARS-CoV2 belongs to $\beta$-coronaviruses genera of coronaviridae family of Nidovirales order [7]. SARS-CoV2, with a diameter ranged between $80-220 \mathrm{~nm}$, is an enveloped virus containing single-stranded positive sense RNA with 26-32 kb genome [3]. Even though different animals were claimed as to be the origin of SARS-CoV2, there is no consensus, and a number of scientists and governmental authorities claim the virus is man-made [2], which idea is supported by such other papers [8,9]. SARS-CoV2 binds to angiotensin-converting enzyme 2 (ACE2) using its receptor binding domain (RBD), followed by entry into the host cells via fusion [10]. Transmembrane serine protease 2 is also vital for the virus entry [11]. Then, the RNA is released and propagated by the host cells, where Golgi packs the whole new viruses, and the packed viruses are released from the host by exocytosis [12]. SARS-CoV2 evades early innate immune response such as interferons [13], details can be found elsewhere [14]. The virus disrupts endothelial integrity, increases neoaginogenesis, causes pneumonia, and endotheliopathies (resulted from hyperinflammation and dysregulated immunity) [15]. The reason lying beneath the proinflammatory disease state of the infection has relation with the decreased IFN-I/-III levels and elevated chemokine expression, which disrupts innate immunity [16]. SARS-CoV2 can recognize such cells other than the ones found in respiratory system through the cellular receptors, including intestinal epithelial cells, alveolar macrophages, dendritic cells, renal tubules, endothelial cells and cerebral neurons [14]. Rare outcomes of SARS-CoV2 infections were also reported, such as 6year old male with SARS-CoV2 PCR (+) developed hyper IgG syndrome and Bell's palsy [17]. Even though SARS-CoV2 infection can affect different organs at different levels, the pathogenicity still shares similarities. Upon SARS-CoV2 infection, a series of changes occur as metabolomic, lipidomic [18], proteomics arrangements (as of changes in proteostasis) and in nucleic acid metabolism and cellular signaling pathways [19]. Molecular aspects of SARS-CoV2 infection were studied using in vitro models and convalescent sera. Bojkova et al (2020) showed that, based on an in vitro study, some portions of the cluster proteins involving in cholesterol metabolism, carbon metabolism and RNAmodification steps (e.g. spliceosome) are altered. The findings revealed that splicing is essential pathway during SARS-CoV2 replication [19]. Besides, the proteins involving in blood coagulation (e.g. D-dimer), inflammatory response (e.g. C-reactive protein) and cell damage (e.g. lactate dehydrogenase) are increased in convalescent sera [20]. Lipoprotein metabolism is of important for homeostasis, and its intermediates are predictive biomarkers for liver conditions. Bruzzone et al (2020) reported, based on a cohort study, the increased convalescent sera levels of triglyceride (TG)high density lipoprotein (HDL), TG-intermediate density lipoprotein (IDL), TG-low density lipoprotein (LDL) and TG-very low-density lipoprotein (VLDL) while increased total cholesterol (TC) content along with decreased TC-LDL and TC-HDL and increased TC-IDL and TC-VLDL content. Even though Apo-A1 and ApoA2 ratio did not alter, their levels gave decrease along with two-fold increased Apo-B and Apo-A1 ratio [18], which is possibly one of the contributors of Covid-19 related increased cardiovascular risks. Actually, dysregulation in lipid metabolism (e.g. arachidonic acid metabolism) is of a prerequisite for SARS-CoV2 propagation [21]. Convalescent sera levels of acetone, acetoacetic acid and 3-hydroxybutyric acid along with the levels of glucose ( 1.7 fold), pyruvic acid, citric acid, glutamic acid and succinic acid increased. Similarly, phenylalanine and 2-hydroxybutyric acid levels increased while tyrosine, histidine, isoleucine, glutamine and methionine levels decreased. The impairment in mitochondrial function, alteration in glucose metabolism and increased oxidative stress agent concentration along with dysregulated lipoprotein metabolism upon Covid19 infection causes liver issues [18].

SARS-Cov2 showed more aggressive transmission rate in comparison to the other known SARS-CoVs. In relation to the contagious character, a great effort has been given on the development of treatment and prevention procedures. However, no universally accepted effective treatment procedures has been developed [22]. Another important aspect of the applied treatment methods that they have been altered overtime due to the fact that either the procedures are not effective, or they showed more detrimental character to the patients more than SARS-CoV2 posed. Therefore, vaccination is currently accepted as the golden approach to overcome SARS-CoV2 pandemic. Currently mRNAbased vaccines are more commonly utilized worldwide to fight against the pandemic, while such other types vaccines including inactivated virus, DNA, protein 
subunit and viral vector are either used or under development $[23,24]$.

Public opinion on new SARS-CoV2 vaccines is strongly influenced by the vaccine reliability and trustworthy of the authorities [25-28]. Australian based study showed that political preferences also a driving force to accept or refuse the vaccination [29]. Immunity towards SARS$\mathrm{CoV} 2$ vaccines is not granted for lifetime, rather the protection is less than a year [25]. It is important to note that vaccination does not prevent individuals spread the SARS-CoV2 infection, especially this is valid for more aggressive ones including Delta variant [30], whose load is similar in fully vaccinated and unvaccinated individuals [31]. Even though there are papers claiming that vaccination can provide herd-immunity, these papers don't rely on scientific evidences, and a survey revealed that majority $(71 \%)$ doesn't either think or know if the vaccination will bring community immunity [32]. Even though single dose of Pfizer/BioNTech vaccine can provide strong immunity against SARSCoV2 infection, Israelis left the cautions before the vaccination developed the immunity, so the infection started to rise. This is at first misunderstood as that vaccination is not protective, but later the reason was found out [33]. The studies done in the USA showed that application of mRNA based vaccines (Moderna and Pfizer/BioNTech) at two-dose protects the individuals as $86 \%$ and $84 \%$ for 2-12 weeks and 13-24 weeks periods, respectively, where the highest protection decrease was reported as $\sim 50 \%$ for $13-24$ weeks periods in immunocompromised individuals [34]. Besides, there is an increasing concern that mutations can break the adaptive immunity when the mutations altered viral protective epitopes [25]. Therefore, there is a great effort on how new mutations will bring new clinical manifestations resulted from the infection [35], so further studies will help to understand the relation between pathogenicity and the mutations.

\section{EFFECTIVENESS OF THE mRNA SARS- COV2 VACCINES}

There are two types of immunity so called as (a) innate (or natural), (b) adaptive immunity. Innate immunity is the first mechanism of defense system fighting against invading pathogens through utilization of innate immune system components including physical barriers, enzymes, macrophages, dendritic cells, mucosal secretions, antimicrobial peptides, granulocytes, polymorphonucleocytes, natural killer (NK) cells, the complement system, and the acute-phase proteins [36]. The power of innate immunity is that its broad and nonspecific activity relying on pattern recognition receptor (PRP) sensors recognizing pathogen-associated molecular patterns (PAMPs) along with its ability to trigger multiple pathways [25]. Adaptive immunity is the acquired immunity upon pathogen infection, and specific to the pathogen. Adaptive immunity utilizes $\mathrm{B}$ and $\mathrm{T}$ cells, and antibodies. B- and T- cells play key roles in defense mechanism against viral infections. B-cells are in charge of antibody production that recognizes viral proteins and prevent the infection [37]. T-cells recognize viruses through cell surface Major Histocompatibility Complex (MHC) classes I and II complexed with viral peptides. T-cells (CD8+ T cells) recognizes MHC class I complexed with viral peptides, so they attack only the cells in which virus is replicating; T-cells either directly lysis the infected cells or they secrete antiviral cytokines including IFN $\gamma$, which turns into elimination of virus propagation and prevention of the infection development. CD4+ helper $\mathrm{T}$ cells recognize viral proteins complexed with MHC Class II. Helper T cells are expressed by dendritic cells, monocytes, and macrophages. They produce cytokines including IL-2, IL-21, IFN $\gamma$ and tumor necrosis factor- alpha (TNF- $\alpha$ ). The cytokines, then, support maturation of CD8 T cells and $\mathrm{B}$ cells along with expanding their performance. It is noteworthy to mention that elimination of different viral infections may require involvement of either mainly B cells or $\mathrm{T}$ cells [37]. Immune cells express, as part of innate immunity, PRRs (e.g., Toll like receptors) sensors recognizing PAMPRs. The sensor units of $\mathrm{B}$ cells are membrane immunoglobulins while $\mathrm{T}$ cells have receptors, all which are called antigen receptors. The sensory units are very sensitive to the pathogens through recognizing epitopes within the protein blocks or subunits of the proteins. Innate immunity and adaptive immunity works coherently to fight against any invasion [36].

In the case of SARS-CoV2, viral RNA nucleotide sequence is recognized by host cellular receptors including TLR3 and TLR7, which are key to activate natural killer (NK) cells, monocytes and IFN expression [25]. It is reported as that innate immunity is very critical to control SARS-CoV2 infection [25,38,39]. Pfizer/BioNTech vaccination induced production of IFN $\gamma$ at $2000 \mathrm{pg} / \mathrm{mL}$ while that was obtained as 50 $\mathrm{pg} / \mathrm{mL}$ for Sinovac vaccination, which is similar to Astrazeneca-Adenoviral vaccine [37]. Production of IFN $\gamma$ is an important marker of developed immunity. Not every SARS-CoV2 patients produce specific IgG antibody (an important marker of adaptive immunity development), but still they survive, where the survival was related to innate immunity [40]. Another important observation was that South African variant showed resistance to convalescent plasma and plasma of mRNA vaccinated individuals, which may lessen the effectivity of current vaccines [41] when the protection is thought only from the adaptive immunity. Blood serums of the patients having asymptomatic or symptomatic SARSCoV2 infection give different antibody and T-cell presence. Many individuals develop innate and adaptive immunization within 3-5 days while patients living severe conditions show the development more than 15days from the onset of the infection [37]. From the data provided in literature, it is clear to say that adaptive and natural immunity are in coordination to fight against SARS-CoV2 infection [42].

Development of SARS-CoV2 specific T-cells is important to fight against the infection [37]. Individuals vaccinated with two dose Pfizer/BioNTech, who 
suffered from hemodialysis (HD), aged between 37-90 ( $\mathrm{n}=72)$, gave average $597.0 \mathrm{AU} / \mathrm{mL}$ antibody titer, where healthy hospital workers (HCWs) average 800.0 $\mathrm{AU} / \mathrm{mL}$ antibody titer (aged between 41-55, $\mathrm{n}=16$ ). It should be noted that the level of antibody titer gave inverse relation with the age for HD patients, and 5 out of 72 patients did not give any antibody development [43]. HCWs $(\mathrm{n}=108)$ gave $123.33 \mathrm{U} / \mathrm{mL}$ (ranged between 27.55 and $464 \mathrm{U} / \mathrm{mL}$ ) anti-RBD (recognition binding domain) $\mathrm{IgG}$ values, where over $50 \%$ gave 100 $\mathrm{U} / \mathrm{mL}$ anti-RBD IgG values. The mean IFN $\gamma 1513$ $\mathrm{mIU} / \mathrm{mL}$ (ranged between 145-2500 mIU/mL). Elderly people $(76-99, \mathrm{n}=15)$ gave $217 \mathrm{U} / \mathrm{mL}$ (ranged between 3 and $500 \mathrm{U} / \mathrm{mL}$ ) anti-RBD $\operatorname{IgG}$ values, and the mean IFN $\gamma 1167 \mathrm{mIU} / \mathrm{mL}$ (ranged between 83-2500 $\mathrm{mIU} / \mathrm{mL}$ ) [44]. It should be noted that mRNA SARS-CoV2 vaccines are specific to $\mathrm{S} 1$ subunit but not to RBD, so this means the protection provided by the vaccine is beyond the proposed mechanism.

Avidity refers to the binding strength of IgG to its target epitope, and play crucial role in protection of individuals against SARS-CoV2 infection [45]. Struck et al (2021) reported that most of the SARS-CoV2 patients did not develop completed avidity IgG against nuclear capsid protein (NP), RBD and S1 while two-dose vaccination triggered development of mature IgG against RBD and S1. It is not common for all the SARS-CoV2 infected patients have mature avidity IgG against RBD, while one dose vaccination triggered completed IgG avidity towards RBD for the infected individuals [45]. Individuals have incomplete avidity IgG towards RBD can trigger enhanced destruction on the individuals undergoing re-infection by SARS-CoV2 [45]. Hall et al (2021) reported the effectiveness of two dose Moderna vaccination for the patients underwent solid organ transplant. $34.5 \%$ of the patients $(n=127)$ gave anti-RBD positive, among the positive patients $28.5 \%$ did not give neutralizing antibody while overall blood serum of $26.9 \%$ patients gave positive neutralizing antibody. $47.9 \%$ of the patients $(n=48)$ gave CD4+ T cells, and among the positive patients $46.2 \%$ did not give antiRBD positive. However, in all cases, CD8+ T cells were not detectable for any of the patients [46], which can be related to the detection method or the applied procedure. Besides, the study done by Sahin et al (2021) reported increased CD4+ $\mathrm{T}$ cells specific to SARS-CoV-2 S protein for the individuals (18-55 years old, $\mathrm{n}=37$ ) vaccinated with Pfizer/BioNTech mRNA vaccine. De novo $\mathrm{S}$-specific $\mathrm{CD} 8+\mathrm{T}$ cell response was detected in sera of 33 participants. S-specific CD4+ T cell responses gave positive correlation with S1-binding IgG. Vaccine induced secretion of IFN $\gamma$, IL-2 by S-specific CD4+ T cells secreted or both, while barely detected $\mathrm{T}$ cells secreting the $\mathrm{T}$ helper 2 cell cytokine IL- 4 were not detected. S-specific CD8+ T cells secreted primarily IFN $\gamma$ and lower levels of IL-2 in response to S1 and S2 stimulation. The fraction of IFN $\gamma$ and IL-2 cytokineproducing $\mathrm{T}$ cells induced by the vaccine strongly increased by day 29 , followed by decline was observed until the day 43 and then gave stabilized levels the day 85 [47]. Similarly, Tarke et al. (2021) show that SARS-
CoV-2- specific memory CD4 and CD8 T cells induced by infection or vaccination recognized the variants including the UK, South Africa, Brazil and Southern California. Both Pfizer/BioNTech and Moderna COVID19 mRNA vaccines gave similar total CD4+ or CD8+ T cell reactivity towards these variants [48]. Based on these presented studies, mRNA-based vaccinations can provide protection against both healthy and chronic disease bearing individuals. Besides, some convalescent sera show markers of immunity development while some doesn't show. It is noteworthy to mention that mutant variants (e.g. delta variant) decrease the effectiveness, for example the effectivity decreased from $74.7 \%$ to $53.1 \%$ for nursing home individuals upon predominant spread of delta variant [49]. For example, the high decrease of BioNTech vaccine effectiveness against delta variant in Israel may call booster vaccination against new aggressive variants [50].

Kalimuddin et al (2021) reported that spike proteinbinding antibodies and spike-specific $\mathrm{T}$ cells could be the underlying reason of vaccine efficacy of one-dose of Pfizer/BioNTech SARS-CoV2 vaccine $(\mathrm{HCW}, \mathrm{n}=20)$, while neutralizing antibodies did not show any involvement. Development of adaptive immunity after one-dose vaccination requires 10-day to form SARSCoV2 spike (S) protein specific immunoglobulin $G$ (IgG), IgA and IgM [51]. However, interestingly some studies showed that uninfected sera can possess specific antibodies against SARS-CoV2 as well, for example from three young individuals $(\mathrm{n}=101)$ and five pregnant women $(\mathrm{n}=50)$ gave SARS-CoV2 $\mathrm{S}$ reactive $\mathrm{IgG}$, which were mainly against $\mathrm{S} 2$ subunit [52]. Sera of individuals underwent SARS-CoV2 infection with single-dose vaccination with Pfizer/BioNTech gave neutralizing antibodies similar to two-dose vaccinated individuals [53], and it was also shown that the single dose vaccination for SARS-CoV2 infected individuals developed neutralizing antibody responses against the variants [54]. However, it should be noted that vaccine efficacy correlation with production of antibodies is still not clear [55]. Even though vaccination after infection can boost the immune response that can tackle with variants, presence of RBD-specific memory $B$ cells in convalescent sera are present up to 1 year [56], so this can raise a question whether a further vaccination should be administrated to the infected individuals or not. Furthermore, based on theoretical studies, natural immunity is better than vaccine mediated immunity in general [57]. Hereby it is noteworthy to mention that one-dose of vaccination after infection is more protective than two-dose vaccination as well [31]. Another important observation is that natural immunity upon infection still protects its capacity against new variants (e.g. delta variant), and the loss in the effectivity is less than those obtained for fully Pfizer/BioNTech vaccinated immunity [58]. Besides, in an Austria based study showed that the protection against reinfection among previously infected individuals are similar to those who were fully vaccinated [59]. Besides, an Israeli based study ( $\mathrm{n}=778658)$ revealed that reinfection by deltavariant for pre-infected individuals is 13-timess less than 
fully vaccinated individuals [60]. Therefore, it is acceptable to ask, why is there a strict vaccination campaign for the infected individuals when there is strong evidence that natural immunity is enough and even better than vaccine mediated immunity? Besides, it should be noted that even two-dose mRNA based vaccination related de novo neutralizing antibodies lose power for certain variants, so current mRNA vaccines may lose their protection against future aggressive variants [61]. However, Peterson et al (2020) showed that $6.3 \%$ of the SARS-CoV2 confirmed cases $(n=2547)$ did not show any $\mathrm{IgG}$ antibody independent from severity of Covid-19 [62], so the evaluation criterion of that whether infections or vaccination will continue protect individuals from re-infection based on presence of $\mathrm{IgG}$ antibodies is not valid for everyone. Similarly, Schwarzkopf et al (2021) reported that $13 \%$ of the convalescent sera $(n=78)$ did not show any detectable $\mathrm{IgG}$, and among these $78 \%$ showed T-cell immunity against SARS-CoV2 infection. This refers to that survival against SARS-CoV2 infection has close relation with cellular immunity rather than IgG development [63]. Therefore, it is clear that it is not logical to evaluate infected or vaccinated individuals' resistance towards reinfection by only relying on IgG tests. Probably another important thing is that SARS-CoV2 infection triggers polyclonal antibody (e.g., polyclonal IgG) production, whose levels depend on the severity of the infection, so the test methods and used anti-IgG type will be important in terms of meaningful resistance evaluation as well.

\section{SIDE-EFFECTS OF mRNA SARS-COV2 VACCINES}

Some of the common side effects of mRNA SARSCoV2 vaccines are headache $(15.4 \%)$, myalgia $(10.5 \%)$, chest pain $(2.8 \%)$, diarrhea $(4.8 \%)$, rhinorrhea $(4.2 \%)$, cough $(2.1 \%)$, irritability $(2.8 \%)$ and dysgeusia $(1.4 \%)$. The first and second doses cause the same side effects with minimal increased or decreased percentages [53]. Rare side effects related to mRNA based SARS-CoV2 vaccination were reported as well, including interstitial lung disease [64], rosaceiform eruption [65], peripheral facial nerve palsy [66], anaphylactic reactions $(\sim 1 / 1$ million) [67], Guillain-Barre Syndrome [68], myocarditis [69], thrombocytopenia [70] and purpuric rash (Moderna) [71], systemic inflammatory response syndrome (SIRS) (Moderna) [72], myocardial infarction [73-75], anaphylaxis [76], hearing loss and tinnitus [77]. These rare adverse effects are mostly confined to cases, and it is not possible claim that vaccine itself caused the problem, but it might worsen the present problem, particularly for systemic inflammatory response syndrome [72]. However, it is clear that mRNA based vaccination mediated problems in heart (i.e. myocarditis, Pericarditis and Cardiomyopathy) are proven facts (e.g. \%0.0016 among military members of the US) [78-80]. It is also important to note that rare side effects can even cause deaths [76], and importantly still there is no enough data what these vaccines bring as long-term side effects [81]. There is an ongoing whisper as that mRNA
SARS-CoV2 vaccines can cause infertility in males. Even though there is no long-term research on this, it was shown that both Moderna and Pfizer/BioNTech vaccination increased sperm count and motility in some individuals [82], so possible long-term effects still are debatable. However, it should be noted that a Turkeybased study showed that SARS-CoV2 infection dramatically decreased the sperm count and motility [83].

Currently some countries require mandatory vaccination for certain groups including HCWs [84], which is not accepted by all the individuals [85]. For example, based on an opinion, the lack of knowledge in the long-term effects and vaccine related deaths will cause national treat to the US if the soldiers are required to get SARSCoV2 vaccine [81]. Possible mandated vaccination for the military members of the US call ethical questions as well [86]. Interestingly, certain countries including Turkmenistan (where the number of SARS-CoV2 infected individuals are kept as a state secret) have taken the strictest regulations to make vaccination mandatory for everyone aged over 18-years [87]. However, an Israel based study revealed that beta variant related infection is 8 -times higher in vaccinated individuals in comparison to the unvaccinated individuals [88]. Similarly, $74 \%$ of the delta virus infected patients $(n=469)$ were fully vaccinated while of those $26 \%$ was unvaccinated in MA of the US. Another important observation was the virus load was similar for the fully vaccinated and unvaccinated individuals [89]. Of course, these studies cannot be conclusive about the vaccine effectiveness against aggressive variants including delta because of the fact that a Norwegian study revealed that fully vaccinated individuals are less prone to reinfection with delta virus in comparison to unvaccinated individuals for those who were hospitalized [90]. However, it is clear that SARS-CoV2 specific vaccines are losing their effectiveness against the aggressive variants. Therefore, detailed studies are needed to understand SARS-CoV2 infection along with the vaccination mediated protection in order to provide a better herd immunity [91] without causing vaccination related health issues. Another important side-effect of Covid-19 vaccines are that modelling studies revealed that vaccination can cause vaccine-resistant mutants if transmission is not prevented. So, worldwide mass vaccination must be established simultaneously to lessen vaccine driven aggressive mutant development [92].

\section{CONVENTIONAL CHILDHOOD VACCINES AGAINST SARS-COV2 PANDEMIC}

Children undergo SARS-CoV2 infection live less symptoms in comparison to adults owing to their preactivated innate immunity in the upper airways (here early IFN production is important), and the difference is not related to SARS-CoV2 receptors among children and adults since the receptors are similar, whose details can be reached elsewhere [93]. Conventional vaccines triggers antigen specific responses to train immune system. The trained immune response can prevent other 
infections as well, particularly live attenuated viral vaccines bring the protection up to 5 years [94]. For example, a recent study done with 137037 SARS-CoV2 PCR (+) individuals revealed that the individuals, having conventional vaccination history (1-5 years prior to PCR test), are in the lower risk and higher recovery rate upon SARS-CoV2 infection [94].

SARS-CoV2 spike (S) glycoprotein, measles virus fusion glycoprotein (F1) and rubella virus envelope (E1) share $30 \%$ amino acid sequence. The homologous region is of antigenic epitopes for E1 and F1 glycoproteins. In silico studies, done based on this homology, revealed that Hepatitis B, BCG, Tetanus and Measles vaccines have great potential to protect individuals from SARSCoV2 infection [95]. Hassani et al (2021) reported that convalescent sera of SARS-CoV2 infected patients gave reactivity towards measles [96], which could be related to the aforementioned sequence homology. Lundberg et al (2021) reported that recent MMR vaccination (vaccination was in 2018) in adults provides protection from severe outcomes of SARS-CoV2 for males [97]. Besides, Gold et al (2020) showed that the individuals have $\mathrm{IgG}$ resulted from MMR vaccine in plasma showed strong resistance towards severe outcomes of Covid-19 infection and all showed moderate symptoms [98]. Similarly, a study done with soldiers with SARS-CoV2 PCR (+) who underwent MMR booster vaccination gave lower seropositivity of Covid-19 in comparison to the non-vaccinated ones, so the authors believe that MMR vaccination can be preventative against the severe outcomes [99]. Besides, Mysore et al (2021) showed that there is a protective heterologous $\mathrm{T}$ cell immunity between MMR and SARS-CoV2 (particularly with S1 subunit and nucleocapsid) [100]. An epidemiological study done by Onwude and Sokunbi (2021) showed that SARS-CoV2 infection related death among children are rare (only 6 reported worldwide). The death rates in the US, the UK and Nigeria are 1126/million, 1515/million, and $7.5 /$ million, respectively. Due to measles outbreak in Nigeria, a state-wise MMR vaccination is common in Nigeria, so the rare death rate among children and in Nigeria because of SARS-CoV2 infection are attributed to MMR vaccination [101]. MMR vaccination can be offered to even elderly people against the pandemic along with its benign nature [102]. MMR vaccine administrated individuals $(\mathrm{n}=255)$ since Covid-19 started were monitored how they reacted towards SARS-CoV2 infection. Among them 36 underwent SARS-CoV2 infection (13 of them had chronic diseases including hypertension and diabetes), and all gave mild symptoms. The MMR related protection is attributed to trained innate immunity and heterologous adaptive immunity (which provides cross-reactivity). It is highly probable that the American society of Microbiology was right when they claimed that MMR vaccine can break the impact of Covid-19 pandemic [103].

BCG vaccination is a live attenuated Mycobacterium bovi vaccine that is administrated to 130 million infants annually. BCG vaccination mediated increase of IFN $\gamma$ and IL-10 levels are still protective for elderly people against respiratory tract infection. Retrospective studies revealed that Covid-19 related infections and mortality are lower in the countries have national BCG immunization program. Besides, recovery rates from SARS-CoV2 infection are higher in those countries as well. Therefore, BCG vaccination seems a promising approach to overcome SARS-CoV2 pandemic with its benign nature to human health [104]. In silico studies, based on homology, revealed that BCG vaccination can trigger production of cross-reactive $\mathrm{T}$ cells against SARS-CoV2 [105] along with enhanced innate immunity [106]. Immunohistochemical studies also proved this hypothesis and the theoretical studies [106]. In addition to these, clinical trials of BCG vaccination revealed that the vaccine is effective to combat against SARS-CoV2 infection [107]. Eggenhuizen et al (2021) reported, an in vitro study based on 20 individuals primed with 8 BCG-derived peptides (which show homology to the components of SARS-CoV2), that $\mathrm{CD}^{+}$and $\mathrm{CD}^{+} \mathrm{T}$ cells specific for BCG peptides crossreact with SARS-CoV-2 peptides [108]. These reveal that $\mathrm{BCG}$ vaccination can be protective against SARSCoV2 infections. However, a recent study done in East and West Germany revealed that BCG vaccination history may not provide individuals from severe outcomes of SARS-CoV2 infection [109]. In contrast to this, the study done in Iberian peninsula revealed that BCG vaccination seems a powerful approach to prevent the severe outcomes of the infection, where the authors also warn that the world doesn't have enough BCG vaccines that can be administrated worldwide [110]. Similarly, the study done in the USA with HCW revealed that $\mathrm{BCG}$ vaccination history confers protective effect against severe outcomes of Covid-19 [111]. BCG vaccination doesn't provide lifelong protection against SARS-CoV2 infection [112], so booster BCG vaccination is needed to provide further protection against Covid-19 [113] over its residual protection [114]. However it should be noted that BCG vaccination is still needed in the tuberculosis-risky countries, so shortages can cause issues, and also large randomized studies are needed to see the exact potential of BCG vaccination against this infection [115]. Ongoing clinical trials will help to enlighten the proposed exact potential.

The mechanism behind BCG vaccination and live enterovirus vaccines related outstanding potential to fight against SARS-CoV2 infection is of their nonspecific protective mechanisms. These can be listed as (i) epigenetic modification of monocytes, (ii) crossreaction between B and T cells, (iii) increased IFN- $\gamma$ and enhanced recruitment of innate immune cells resulted from $\mathrm{T}_{\mathrm{H}} 1$ cells differentiation, (iv) production of mucosal $\operatorname{Ig} \mathrm{A} / \mathrm{IgG}$, (v) prevention or decrease in invasive pathogen-host interactions, (vi) early activation of CD4 and CD8 $\mathrm{T}$ cells, (vii) protective anti-inflammatory effects, (viii) early protection against tissue damage and (ix) increased polymorphonuclear leukocyte synthesis. For instance, CoV-2 suppresses TLR signaling when it shows its pathogenicity, and it is known that immunization with live vaccines (e.g. OPV) can activate innate immunity via pre-activation of TLRs and prime 
the immune system for adaptive immunity upon infection with SARS-CoV2 [36]. Due to these reasons and retrospective studies, BCG vaccination is seen viable alternative to SARS-CoV2 specific vaccines for those who don't have access (at least) [107] or do not want current mRNA SARS-CoV2 specific vaccines.

\section{BRIEF COMPARISON OF PRIOR INFECTION, mRNA-BASED SARS-COV2 VACCINES AND TRADITIONAL CHILDHOOD VACCINES.}

There are two main reasons lying behind the remark 'even better' given in the paper. (i) Infection mediated immunity and mRNA vaccine mediated immunity rely on different mechanisms. mRNA vaccines result in overwhelmingly specific antibody production against the spike protein while infection results in antibody production against different antigenic regions of the SARS-CoV2. (ii) Prior infections trigger larger cellular and mucosal immunity in comparison to the mRNA based vaccines. mRNA-based vaccines do not contribute mucosal immunity, so vaccinated individuals still can get infected and SARS-CoV2 viruses can propagate within nasal cells [116], which makes the vaccinated individuals perfect SARS-CoV2 spreader when they get infected. Vaccine mediated protection against Covid-19 infection is interestingly related to the levels of antibody, however it is clear that absence of antibody in serum doesn't refer to that there is no protection. Memory B-cells upon infection is still active, and provides greater immunity against Covid-19 infection even though some patients do not possess antibody in convalescent sera [117]. It is also noteworthy to mention that $\mathrm{S} 1$ spike protein of SARSCoV2 is highly vulnerable to mutation that causes the virus escape from S1-specific antibody synthesized upon vaccination while vaccine induced $\mathrm{S} 2$ antibody is minimal. However, antibody development against S2 protein is critical to get protected against recurring Covid-19 infections. Similarly, B-memory cells are critical in neutralizing antibody production [118]. In contrast to prior infection and vaccination, traditional childhood vaccines provide cross-reactivity, which relies on memory $\mathrm{T}$-cell activity along with regulated cytokine production in favor of fighting against SARS-CoV2 infection as shown in Table 1. It is noteworthy to mention that Prior infection develops mucosal immunity [119], so even if SARS-CoV2 survivals carry active SARS-CoV2 virus, any contribution to the epidemic will be minimal since mucosal immunity downregulates SARS-CoV2 propagation and decreases the discharge period [120]. Spreading the virus is not related to survived patients, rather it is related to the active vectors.

Table 1. Comparison of natural immunity, SARS CoV2 specific mRNA vaccines and traditional childhood vaccines.

\begin{tabular}{|c|c|c|c|}
\hline Immunity source & Mucosal antibody & Antibody response & Cellular immunity \\
\hline $\begin{array}{l}m R N A \quad S A R S \\
\text { CoV2 vaccine }\end{array}$ & No report found & $\begin{array}{l}S_{1} \text {-binding } \text { antibody }^{I}, \text { Neutralizing } \\
\text { antibody }^{2} ; \text { Slight amount of S2 } \\
\text { antibody, cross-reactive antibodies } \\
\text { against } \beta \text {-coronaviruses }[121] \text {. }\end{array}$ & $\begin{array}{l}\text { Increases in antigen-specific IFN }{ }^{+} \\
C D 4^{+} \text {and } C D 8^{+} T \text { cells; } T_{H} 1 \text { cell } \\
\text { polarization; little change in } T_{H} 2 \text { cell } \\
\text { responses }[122] .\end{array}$ \\
\hline Prior infection* & $\begin{array}{lrr}\operatorname{IgG}, & \operatorname{IgM} & {[120],} \\
\text { and } & I g A \\
\text { production[122]. }\end{array}$ & $\begin{array}{l}\text { Memory } \quad B \quad \text { cells }[123,124] ; \quad S_{1^{-}} \\
\text {binding } \quad \text { antibody, } \quad S_{2} \text {-binding } \\
\text { antibody, Neutralizing antibody, } \\
\text { Nucleocapsid binding antibody, anti } \\
\text { RBD antibody [125]; }\end{array}$ & $\begin{array}{l}\text { Increases in } I F N \gamma^{+} \text {and IL-2 specific } \\
C D 4^{+} \text {and } C D 8^{+} T \text { cells }[126] ; C D 4^{+} \\
T_{H} 1 \text { and } C D 4^{+} T_{H} 2, C D 4+ \\
T_{C M} \text { and CD } 4^{+} I L-22^{+} \quad \text { cell } \\
\text { polarization; increased INFa levels, } \\
\text { mucosal-associated invariant } T \text { and } \\
N K T \text { cells; increased circulating } \\
\text { follicular helper } T \text { cells; increased } \\
C D 1 Q A / B / C^{+} \\
C D 16^{+} \text {monocytes }[123]\end{array}$ \\
\hline BCG vaccination & No report found & $\begin{array}{l}\text { Cross-reactive antibodies, Cross- } \\
\text { reactive B-memory cells [104]. }\end{array}$ & $\begin{array}{l}\text { Cross-reactive dendritic cells (i.e. } \\
\text { inf-cDC2s) that priming type I INF } \\
\text { dependent [114] } \mathrm{CD}^{+} \text {and } \mathrm{CD}^{+} \mathrm{T} \\
\text { cells activation [108]; Down- } \\
\text { regulation of proinflammatory } \\
\text { cytokine production [127]; various } \\
\text { antiviral cytokine production, } \\
\text { enhanced IFN- } \gamma \text { production and } \\
\text { associated } \mathrm{T}_{\mathrm{H}} 1 \text { cells differentiation } \\
{[104] \text {. }}\end{array}$ \\
\hline MMR vaccination & No report found & $\begin{array}{l}\text { Cross-reactive B-memory cells[96] } \\
\text { and cross reactive antibodies[98] } \\
\text { (e.g. anti } R B D \text { antibody }[128])\end{array}$ & $\begin{array}{l}\text { Suppressing SARS-CoV2 interaction } \\
\text { with cells [128]; memory } T \text { cells } \\
\text { recognizing S1 and nucleocapsid } \\
\text { proteins and increased protective } \\
\text { cytokine production [129]. }\end{array}$ \\
\hline
\end{tabular}

*During Covid-19 infection, humoral and cellular immunity cooperates if the patient faces mild or asymptomatic infection while severe infections can break the cooperation [123]. During the literature search the following keywords were used "SARS-CoV2 mRNA vaccine and mucosal antibody", "SARS-CoV2, MMR vaccine and mucosal antibody" or "SARS-CoV2, BCG vaccine and mucosal antibody".

\section{CONCLUSION}

SARS-CoV2 infection is still the major problem of the entire world even though vaccination is increasing rapidly. Despite of the fact that SARS-CoV2 specific vaccines are claimed as the only solution to the pandemic when cost-benefit analysis is considered, decreasing vaccine efficacy against new aggressive variants, rare adverse effects are still formidable along with possible long term-negative effects. In terms of 
rare-side effects, there is no clear information how "How really rare are those rare-side effects". Besides, mutations can weaken the benefits of current SARS$\mathrm{CoV} 2$ specific vaccines, so required the third dose is already under discussion and possible new variant specific vaccines may be needed as well. Also, extensive immunological, biochemical and clinical studies are required to enlighten the parameters need to be taken into account to test whether natural infection is protective enough for current and up-coming aggressive variants before the infected individuals are exposed to further SARS-CoV2 specific vaccines. Alternative to SARS-CoV2 specific vaccines, conventional vaccines (particularly BCG and MMR) may provide strong trained innate immunity and/or heterologous adaptive immunity against SARS-CoV2 infection to resolve Covid-19 pandemic. As a concluding remark, utilization of conventional childhood vaccines against SARS-CoV2 infections should be considered as a valuable approach at all age groups, so further randomized studies combining all age scales on the efficacy of childhood vaccination against SARS-CoV2 pandemic seem critical to bring up a better resolution on the proposed efficacy of the childhood vaccines.

\section{Acknowledgement}

Many thanks to Prof Ergin Murat Altuner of Kastamonu University for constructive comments.

\section{REFERENCES}

[1] $\mathrm{Wu} \mathrm{YC,} \mathrm{Chen} \mathrm{CS,} \mathrm{Chan} \mathrm{YJ.} \mathrm{The} \mathrm{outbreak} \mathrm{of}$ COVID-19: An overview. J Chinese Med Assoc 2020;83:217-20. https://doi.org/10.1097/JCMA.000000000000027 0 .

[2] Ciotti M, Ciccozzi M, Terrinoni A, Jiang WC, Wang C Bin, Bernardini S. The COVID-19 pandemic. Crit Rev Clin Lab Sci 2020;57:36588.

https://doi.org/10.1080/10408363.2020.1783198.

[3] Helmy YA, Fawzy M, Elaswad A, Sobieh A, Kenney SP, Shehata AA. The COVID-19 Pandemic: A Comprehensive Review of Taxonomy, Genetics, Epidemiology, Diagnosis, Treatment, and Control. J Clin Med 2020;9:1225. https://doi.org/10.3390/jcm9041225.

[4] Brandal LT, Ofitserova TS, Meijerink H, Rykkvin R, Lund HM, Hungnes O, et al. Minimal transmission of SARS-CoV-2 from paediatric COVID-19 cases in primary schools, Norway, August to November 2020. Eurosurveillance 2020;26:2002011. https://doi.org/10.2807/15607917.ES.2020.26.1.2002011.

[5] Durrheim DN, Andrus JK, Tabassum S, Bashour H, Githanga D, Pfaff G. A dangerous measles future looms beyond the COVID-19 pandemic. Nat Med 2021;27:360-1. https://doi.org/10.1038/s41591-021-01237-5.

[6] Kalina M, Tilley E. "This is our next problem": Cleaning up from the COVID-19 response. Waste
Manag

2020;108:202-5.

https://doi.org/10.1016/j.wasman.2020.05.006.

[7] Mohamadian M, Chiti H, Shoghli A, Biglari S, Parsamanesh N, Esmaeilzadeh A. COVID-19: Virology, biology and novel laboratory diagnosis. J Gene Med 2021;23:1-11. https://doi.org/10.1002/jgm.3303.

[8] Chaturvedi P, Ramalingam N, Singh A. Is COVID-19 man-made? Cancer Res Stat Treat 2020;3:284.

[9] Segreto R, Deigin Y. The genetic structure of SARS-CoV-2 does not rule out a laboratory origin SARS-COV-2 chimeric structure and furin cleavage site might be the result of genetic manipulation. BioEssays 2021;43:2000240. https://doi.org/10.1002/bies.202000240.

[10] Shang J, Wan Y, Luo C, Ye G, Geng Q, Auerbach A, et al. Cell entry mechanisms of SARS-CoV-2. Proc Natl Acad Sci USA $2020 ; 117$. https://doi.org/10.1073/pnas.2003138117.

[11] Li F, Han M, Dai P, Xu W, He J, Tao X, et al. Distinct mechanisms for TMPRSS2 expression explain organ-specific inhibition of SARS-CoV-2 infection by enzalutamide. Nat Commun 2021;12:1-14. https://doi.org/10.1038/s41467021-21171-x.

[12] Kumar V, Doshi KU, Khan WH, Rathore AS. COVID-19 pandemic: mechanism, diagnosis, and treatment. J Chem Technol Biotechnol 2021;96:299-308. https://doi.org/10.1002/jctb.6641.

[13] Or Caspi, Michael J. Smart RBN. Adaptive immunity to SARS-CoV-2 and COVID-19 Alessandro. Cell 2021.

[14] Amor S, Fernández Blanco L, Baker D. Innate immunity during SARS-CoV-2: evasion strategies and activation trigger hypoxia and vascular damage. Clin Exp Immunol 2020;202:193-209.

https://doi.org/10.1111/cei.13523.

[15] Castro P, Palomo M, Moreno-Castaño AB, Fernández S, Torramadé-Moix S, Pascual G, et al. Is the Endothelium the Missing Link in the Pathophysiology and Treatment of COVID-19 Complications? Cardiovasc Drugs Ther 2021. https://doi.org/10.1007/s10557-021-07207-w.

[16] Blanco-Melo D, Nilsson-Payant BE, Liu WC, Uhl S, Hoagland D, Møller R, et al. Imbalanced Host Response to SARS-CoV-2 Drives Development of COVID-19. Cell 2020;181:10361045.e9.

https://doi.org/10.1016/j.cell.2020.04.026.

[17] Theophanous C, Santoro JD, Itani R. Bell's palsy in a pediatric patient with hyper IgM syndrome and severe acute respiratory syndrome coronavirus 2 (SARS-CoV-2). Brain Dev 2021;43:357-9. https://doi.org/10.1016/j.braindev.2020.08.017.

[18] Bruzzone C, Lu S, Diercks T, Arana E, Gil-mart $\mathrm{J}$, Embade $\mathrm{N}$, et al. SARS-CoV-2 Infection Dysregulates the Metabolomic and Lipidomic 
Profiles of Serum the Metabolomic and Lipidomic Profiles of Serum. IScience 2020;23:101645.

https://doi.org/10.1016/j.isci.2020.101645.

[19] Bojkova D, Klann K, Koch B, Widera M, Krause D. Proteomics of SARS-CoV-2-infected host cells reveals therapy targets. Nature 2020;583. https://doi.org/10.1038/s41586-020-2332-7.

[20] Whetton AD, Preston GW, Abubeker S, Geifman N. Proteomics and Informatics for Understanding Phases and Identifying Biomarkers in COVID-19 Disease. J Proteome Res 2020;10:4219-4232. https://doi.org/10.1021/acs.jproteome.0c00326.

[21] Replication C, Yan B, Chu H, Yang D, Sze K, Lai $\mathrm{P}$, et al. for Lipid Metabolism Remodeling upon. Viruses 2019;11. https://doi.org/10.3390/v11010073.

[22] Hanan N, Doud RL, Park IW, Jones HP, Mathew SO. The many faces of innate immunity in SARS-CoV-2 infection. Vaccines 2021;9:1-17. https://doi.org/10.3390/vaccines9060596.

[23] Noh JY, Jeong HW, Shin EC. SARS-CoV-2 mutations, vaccines, and immunity: implication of variants of concern. Signal Transduct Target Ther 2021;6:3-4. https://doi.org/10.1038/s41392021-00623-2.

[24] Lu M, Dravid P, Zhang Y, Trivedi S, Li A, Harder $\mathrm{O}$, et al. A safe and highly efficacious measles virus-based vaccine expressing SARSCoV-2 stabilized prefusion spike. Proc Natl Acad Sci U $\quad$ S $\quad$ A $2021 ; 118$. https://doi.org/10.1073/pnas.2026153118.

[25] Chumakov K, Avidan MS, Benn CS, Bertozzi SM, Blatt L, Chang AY, et al. Old vaccines for new infections: Exploiting innate immunity to control COVID-19 and prevent future pandemics. Proc Natl Acad Sci U S A 2021;118:1-10. https://doi.org/10.1073/pnas.2101718118.

[26] Akarsu B, Canbay Özdemir D, Ayhan Baser D, Aksoy H, Fidanc1 İ, Cankurtaran M. While studies on COVID-19 vaccine is ongoing, the public's thoughts and attitudes to the future COVID-19 vaccine. Int J Clin Pract 2021;75:110. https://doi.org/10.1111/ijcp.13891.

[27] Latkin CA, Dayton L, Yi G, Konstantopoulos A, Boodram B. Trust in a COVID-19 vaccine in the U.S.: A social-ecological perspective. Soc Sci Med 2021;270:113684.

[28] Fadda M, Suggs LS, Albanese E. Willingness to vaccinate against Covid-19: A qualitative study involving older adults from Southern Switzerland. Vaccine $\mathrm{X}$ 2021;8:100108. https://doi.org/10.1016/j.jvacx.2021.100108.

[29] Smith DT, Attwell K, Evers U. Support for a COVID-19 vaccine mandate in the face of safety concerns and political affiliations: An Australian study. Politics 2021:02633957211009066. https://doi.org/10.1177/02633957211009066.

[30] Subbaraman N. How do vaccinated people spread Delta? What the science says. Nature 2021;596:327-8. https://doi.org/10.1038/d41586021-02187-1.
[31] Griffin S. Covid-19: Fully vaccinated people can carry as much delta virus as unvaccinated people, data indicate. Bmj 2021. https://doi.org/10.1136/bmj.n2074.

[32] Korn L, Böhm R, Betsch C. Reply to Rabb et al.: WhypromotingCOVID-

19vaccineswithcommunity immunity is not a good strategy (yet). Proc Natl Acad Sci U S A 2021;118:e2102054118. https://doi.org/10.1073/PNAS.2102054118.

[33] Mahase E. Covid-19: Israel sees new infections plummet following vaccinations. BMJ 2021;372:n338. https://doi.org/10.1136/bmj.n338.

[34] Tenforde MW, Self WH, Naioti EA, Ginde AA, Douin DJ, Olson SM, et al. Sustained Effectiveness of Pfizer-BioNTech and Moderna Vaccines Against COVID-19 Associated Hospitalizations Among Adults - United States, March-July 2021. MMWR Morb Mortal Wkly Rep 2021;70:1156-62. https://doi.org/10.15585/mmwr.mm7034e2.

[35] Burki T. Understanding variants of SARS-CoV-2. Lancet 2021;397:462. https://doi.org/10.1016/S0140-6736(21)00298-1.

[36] Moutsopoulos HM, Zampeli E. Immunology and Rheumatology in Questions. 2nd ed. Cham, Switzerland: $\quad$ Springer; 2021. https://doi.org/10.1007/978-3-030-56670-8.

[37] Bertoletti A, Tan AT, Le Bert N. The T-cell response to SARS-CoV-2: kinetic and quantitative aspects and the case for their protective role. Oxford Open Immunol 2021;2:19. https://doi.org/10.1093/oxfimm/iqab006.

[38] Schijns V, Lavelle EC. Prevention and treatment of COVID-19 disease by controlled modulation of innate immunity. Eur J Immunol 2020;50:9328. https://doi.org/10.1002/eji.202048693.

[39] Golonka RM, Saha P, Yeoh XBS, Chattopadhyay S, Gewirtz AT, Joe B, et al. Harnessing innate immunity to eliminate SARS-CoV-2 and ameliorate COVID-19 disease. Physiol Genomics 2020;52:217-21.

https://doi.org/10.1152/PHYSIOLGENOMICS.0 0033.2020.

[40] Wang B, Wang L, Kong X, Geng J, Xiao D, Ma $\mathrm{C}$, et al. Long-term coexistence of SARS-CoV-2 with antibody response in COVID-19 patients. J Med Virol 2020;92:1684-9. https://doi.org/10.1002/jmv.25946.

[41] Wang R, Zhang Q, Ge J, Ren W, Zhang R, Lan J, et al. Analysis of SARS-CoV-2 variant mutations reveals neutralization escape mechanisms and the ability to use ACE2 receptors from additional species. Immunity 2021;54:1611-1621.e5. https://doi.org/10.1016/j.immuni.2021.06.003.

[42] Jordan SC. Innate and adaptive immune responses to SARS- - 2 in humans : relevance to acquired immunity and vaccine responses. Clin Exp Immunol 2021;204:310-20. https://doi.org/10.1111/cei.13582.

[43] Jahn M, Korth J, Dorsch O, Anastasiou OE, Sorge-Hädicke B, Tyczynski B, et al. Humoral 
response to SARS-CoV-2-vaccination with BNT162b2 (pfizer-biontech) in patients on hemodialysis. Vaccines 2021;9:1-8. https://doi.org/10.3390/vaccines9040360.

[44] Malipiero G, Moratto A, Infantino M, D’Agaro P, Piscianz E, Manfredi M, et al. Assessment of humoral and cellular immunity induced by the BNT162b2 SARS-CoV-2 vaccine in healthcare workers, elderly people, and immunosuppressed patients with autoimmune disease. Immunol Res 2021. https://doi.org/10.1007/s12026-021-09226$\mathrm{z}$.

[45] Struck F, Schreiner P, Staschik E, WochinzRichter K, Schulz S, Soutschek E, et al. Vaccination versus infection with SARS-CoV-2: Establishment of a high avidity IgG response versus incomplete avidity maturation. J Med Virol 2021:1-13. https://doi.org/10.1002/jmv.27270.

[46] Hall VG, Ferreira VH, Ierullo M, Ku T, Marinelli T, Majchrzak-Kita B, et al. Humoral and cellular immune response and safety of two-dose SARSCoV-2 mRNA-1273 vaccine in solid organ transplant recipients. Am J Transplant 2021:1-10. https://doi.org/10.1111/ajt.16766.

[47] Sahin U, Muik A, Vogler I, Derhovanessian E, Kranz LM, Vormehr M, et al. BNT162b2 vaccine induces neutralizing antibodies and poly-specific $\mathrm{T}$ cells in humans. Nature 2021;595:572-7. https://doi.org/10.1038/s41586-021-03653-6.

[48] Tarke A, Sidney J, Methot N, Yu ED, Zhang Y, Dan JM, et al. Impact of SARS-CoV-2 variants on the total CD4+ and CD8+ $\mathrm{T}$ cell reactivity in infected or vaccinated individuals. Cell Reports Med 2021;2:100355. https://doi.org/10.1016/j.xcrm.2021.100355.

[49] Nanduri S, Pilishvili T, Derado G, Soe MM, Dollard P, Wu H, et al. Effectiveness of PfizerBioNTech and Moderna Vaccines in Preventing SARS-CoV-2 Infection Among Nursing Home Residents Before and During Widespread Circulation of the SARS-CoV-2 B.1.617.2 (Delta) Variant - National Healthcare Safety Network, March 1-August. vol. 70. 2021. https://doi.org/10.15585/mmwr.mm7034e3.

[50] Goldberg Y, Mandel M, Bar-On YM, Bodenheimer O, Freedman L, Haas EJ, et al. Waning immunity of the BNT162b2 vaccine: A nationwide study from Israel. 2021.

[51] Harrington P, Doores KJ, Radia D, O'Reilly A, Lam HPJ, Seow J, et al. Single dose of BNT162b2 mRNA vaccine against severe acute respiratory syndrome coronavirus-2 (SARS-CoV2) induces neutralising antibody and polyfunctional $\mathrm{T}$-cell responses in patients with chronic myeloid leukaemia. $\mathrm{Br} \mathrm{J}$ Haematol 2021;2. https://doi.org/10.1111/bjh.17568.

[52] $\mathrm{Ng} \mathrm{KW}$, Faulkner $\mathrm{N}$, Cornish GH, Rosa A, Harvey R, Hussain S, et al. Preexisting and de novo humoral immunity to SARS-CoV-2 in humans. Science (80- ) 2020;370:1339-43. https://doi.org/10.1126/science.abe1107.
[53] Morales-Núñez JJ, Muñoz-Valle JF, Meza-López C, Wang LF, Sulbarán ACM, Torres-Hernández PC, et al. Neutralizing antibodies titers and side effects in response to bnt $162 \mathrm{~b} 2$ vaccine in healthcare workers with and without prior sarscov-2 infection. Vaccines 2021;9. https://doi.org/10.3390/vaccines9070742.

[54] Reynolds CJ, Pade C, Gibbons JM, Butler DK, Otter AD, Menacho K, et al. Responses To Variants After First Vaccine Dose. Science (80- ) 2021;1423:1418-23.

[55] Borgonovo F, Passerini M, Piscaglia M, Morena V, Giacomelli A, Oreni L, et al. Is COVID-19 severity associated with anti-spike antibody duration? Data from the ARCOVID prospective observational study. J Infect 2021.

[56] Wang Z, Muecksch F, Schaefer-Babajew D, Finkin S, Viant C, Gaebler C, et al. Naturally enhanced neutralizing breadth against SARSCoV-2 one year after infection. Nature 2021;595:426-31. https://doi.org/10.1038/s41586-021-03696-9.

[57] Kabir KMA, Tanimoto J. Analysis of individual strategies for artificial and natural immunity with imperfectness and durability of protection. J Theor Biol 2021;509:110531. https://doi.org/10.1016/j.jtbi.2020.110531.

[58] Tada T, Dcosta BM, Samanovic MI, Herati RS, Cornelius A, Zhou H, et al. Convalescent-Phase Sera and Vaccine-Elicited Antibodies. MBio 2021;12:e0669-21.

[59] Pilz S, Chakeri A, Ioannidis JPA, Richter L, Theiler-Schwetz V, Trummer C, et al. SARSCoV-2 re-infection risk in Austria. Eur $\mathrm{J}$ Clin Invest 2021;51:1-7. https://doi.org/10.1111/eci.13520.

[60] Gazit S, Shlezinger R, Perez G, Lotan R, Peretz A, Ben-Tov A, et al. Comparing SARS-CoV-2 natural immunity to vaccine-induced immunity: reinfections versus breakthrough infections. 2021. https://doi.org/10.1016/b978-0-12-8205464.00017-9.

[61] Wang P, Nair MS, Liu L, Iketani S, Luo Y, Guo $\mathrm{Y}$, et al. Antibody resistance of SARS-CoV-2 variants B.1.351 and B.1.1.7. Nature 2021;593:130-5. https://doi.org/10.1038/s41586021-03398-2.

[62] Petersen LR, Sami S, Vong N, Pathela P, Weiss $\mathrm{D}$, Morgenthau BM, et al. Lack of antibodies to SARS-CoV-2 in a large cohort of previously infected persons. Clin Infect Dis an Off Publ Infect Dis Soc Am 2020:ciaa1685.

[63] Schwarzkopf S, Adalbert Krawczyk, Knop D, Klump H, Heinold A, Heinemann FM, et al. Cellular Immunity in COVID-19 Convalescents with PCR-Confirmed Infection but with Undetectable SARS-CoV-2-Specific IgG. Emerg Infect Dis 2021;27:122.

[64] Park JY, Kim JH, Lee IJ, Kim H Il, Park S, Hwang Y Il, et al. COVID-19 vaccine-related interstitial lung disease: A case study. Thorax 2021:1-3. https://doi.org/10.1136/thoraxjnl-2021- 
217609.

[65] Ciccarese G, Drago F, Rebora A, Parodi A. Two cases of papulo-pustular rosacea-like eruptions following COVID-19 vaccinations. J Eur Acad Dermatology Venereol 2021. https://doi.org/10.1111/jdv.17615.

[66] Shemer A, Pras E, Einan-Lifshitz A, DubinskyPertzov B, Hecht I. Association of COVID-19 Vaccination and Facial Nerve Palsy: A CaseControl Study. JAMA Otolaryngol - Head Neck Surg 2021;147:739-43. https://doi.org/10.1001/jamaoto.2021.1259.

[67] de Vrieze J. Pfizer's vaccine raises allergy concerns. Science (80- ) 2021.

[68] Waheed S, Bayas A, Hindi F, Rizvi Z, Espinosa PS. Neurological Complications of COVID-19: Guillain-Barre Syndrome Following Pfizer COVID-19 Vaccine. Cureus 2021;13:2. https://doi.org/10.7759/cureus.13426.

[69] Nassar M, Nso N, Elshafey M, Abdalazeem Y, Nyein A, Punzalan B, et al. COVID-19 vaccineinduced myocarditis: Case report with literature review. Diabetes Metab Syndr Clin Res Rev 2020; $15: 102205$.

[70] Lee EJ, Cines DB, Gernsheimer T, Kessler C, Michel M, Tarantino MD, et al. Thrombocytopenia following Pfizer and Moderna SARS-CoV-2 vaccination. Am J Hematol 2021;96:534-7.

https://doi.org/10.1002/ajh.26132.

[71] Malayala S V, Mohan G, Vasireddy D, Atluri P. Purpuric Rash and Thrombocytopenia After the mRNA-1273 (Moderna) COVID-19 Vaccine. Cureus 2021;13:3. https://doi.org/10.7759/cureus.14099.

[72] Steinberg J, Thomas A, Iravani A. 18Ffluorodeoxyglucose PET/CT findings in a systemic inflammatory response syndrome after COVID-19 vaccine. Lancet 2021;397:e9. https://doi.org/10.1016/S0140-6736(21)00464-5.

[73] Chatterjee S, Ojha UK, Vardhan B. Myocardial infarction after COVID-19 vaccination-casual or causal? Diabetes Metab Syndr Clin Res Rev 2021.

[74] Albert E, Aurigemma G, Saucedo J, Gerson DS. Myocarditis following COVID-19 vaccination. Radiol Case Reports 2021;16:2142-5. https://doi.org/10.1016/j.radcr.2021.05.033.

[75] Deb A, Abdelmalek J, Iwuji K, Nugent K. Acute Myocardial Injury Following COVID-19 Vaccination: A Case Report and Review of Current Evidence from Vaccine Adverse Events Reporting System Database. J Prim Care Community Heal 2021;12:0-4. https://doi.org/10.1177/21501327211029230.

[76] Jain VK, Iyengar KP, Ish P. Elucidating causes of COVID-19 infection and related deaths after vaccination. Diabetes Metab Syndr Clin Res Rev 2021; 15:102212.

https://doi.org/10.1016/j.dsx.2021.102212.

[77] Wichova H, Miller ME, Derebery MJ. Otologic Manifestations After COVID-19 Vaccination:
The House Ear Clinic Experience. Otol Neurotol 2021;42:e1213-8. https://doi.org/10.1097/mao.0000000000003275.

[78] Cereda A, Conca C, Barbieri L, Ferrante G, Tumminello G, Lucreziotti S, et al. Acute myocarditis after the second dose of SARS-CoV2 vaccine: Serendipity or atypical causal relationship? Anatol J Cardiol 2021;25:522-3. https://doi.org/10.5152/AnatolJCardiol.2021.99.

[79] Pepe S, Gregory AT, Denniss AR. Myocarditis, Pericarditis and Cardiomyopathy After COVID19 Vaccination. Hear Lung Circ 2021;30:1425-9. https://doi.org/10.1016/j.hlc.2021.07.011.

[80] Montgomery J, Ryan M, Engler R, Hoffman D, McClenathan B, Collins L, et al. Myocarditis following Immunization with mRNA COVID-19 Vaccines in Members of the US Military. JAMA Cardiol 2021;92134:1-5. https://doi.org/10.1001/jamacardio.2021.2833.

[81] Stephanie Seneff, Greg Nigh. Worse Than the Disease? Reviewing Some Possible Unintended Consequences of the mRNA Vaccines Against COVID-19. Int $\mathrm{J}$ Vaccine Theory, Pract Res 2021;2:402-43.

[82] Gonzalez DC, Nassau DE, Khodamoradi K, Ibrahim E, Blachman-Braun R, Ory J, et al. Sperm Parameters Before andAfter COVID19mRNA Vaccination. JAMA 2021. https://doi.org/10.1111/jgs.17136.

[83] Pazir Y, Eroglu T, Kose A, Bulut TB, Genc C, Kadihasanoglu M. Impaired semen parameters in patients with confirmed SARS-CoV-2 infection: A prospective cohort study. Andrologia 2021;53:e14157. https://doi.org/10.1111/and.14157.

[84] Frati P, Russa R La, Fazio N Di, Fante Z Del, Delogu G, Fineschi V. Compulsory Vaccination for Healthcare Workers in Italy for the Prevention of SARS-CoV-2 Infection. Vaccines 2021;9:966.

[85] Stokel-Walker C. Covid-19: The countries that have mandatory vaccination for health workers. BMJ 2021:273. https://doi.org/10.1136/bmj.n327.

[86] Krick MJA, Reese MTR. Mandating the COVID19 Vaccine for U.S. Service Members: An Exploration of Ethical Arguments. Mil Med 2021.

[87] Dyer O. Covid-19: Turkmenistan becomes first country to make vaccination mandatory for all adults. BMJ 2021. https://doi.org/10.1136/bmj.n1766.

[88] Boehm E, Kronig I, Neher RA, Eckerle I, Vetter P, Kaiser L, et al. Novel SARS-CoV-2 variants: the pandemics within the pandemic. Clin Microbiol Infect J 2021;27:1109-17.

[89] Brown CM, Vostok J, Johnson H, Burns M, Gharpure R, Sami S, et al. Outbreak of SARSCoV-2 Infections, Including COVID-19 Vaccine Breakthrough Infections, Associated with Large Public Gatherings — vol. 70. 2021.

[90] Seppälä E, Veneti L, Starrfelt J, Danielsen AS, Bragstad K, Hungnes $\mathrm{O}$, et al. Vaccine effectiveness against infection with the Delta (B.1.617.2) variant, Norway, April to August 
2021. Eurosurveillance 2021;26:2100793. https://doi.org/10.2807/1560-

7917.es.2021.26.35.2100793.

[91] Roberts AT, Piani F, Longo B, Andreini R, Meini S. Reinfection of SARS-CoV-2-analysis of 23 cases from the literature. Infect Dis (Auckl) 2021;53:479-85. https://doi.org/10.1080/23744235.2021.1905174.

[92] Rella SA, Kulikova YA, Dermitzakis ET, Kondrashov FA. Rates of SARS-CoV-2 transmission and vaccination impact the fate of vaccine-resistant strains. Sci Rep 2021;11:1-10. https://doi.org/10.1038/s41598-021-95025-3.

[93] Loske J, Röhmel J, Lukassen S, Stricker S, Magalhães VG, Liebig J, et al. Pre-activated antiviral innate immunity in the upper airways controls early SARS-CoV-2 infection in children. Nat Biotechnol 2021:1-6. https://doi.org/10.1038/s41587-021-01037-9.

[94] Pawlowski C, Puranik A, Bandi H, Venkatakrishnan AJ, Agarwal V, Kennedy R, et al. Exploratory analysis of immunization records highlights decreased SARS-CoV-2 rates in individuals with recent non-COVID-19 vaccinations. Sci Rep 2021;11:1-20. https://doi.org/10.1038/s41598-021-83641-y.

[95] Haddad-Boubaker S, Othman H, Touati R, Ayouni K, Lakhal M, Ben Mustapha I, et al. In silico comparative study of SARS-CoV-2 proteins and antigenic proteins in $\mathrm{BCG}, \mathrm{OPV}$, MMR and other vaccines: evidence of a possible putative protective effect. BMC Bioinformatics 2021;22:1-14. https://doi.org/10.1186/s12859021-04045-3.

[96] Hassani D, Amiri MM, Maghsood F, Salimi V, Kardar GA, Barati O, et al. Does prior immunization with measles, mumps, and rubella vaccines contribute to the antibody response to COVID-19 antigens? Iran J Immunol 2021;18:47-67.

https://doi.org/10.22034/iji.2021.87990.1843.

[97] Lundberg L, Bygdell M, Stukat von Feilitzen G, Woxenius S, Ohlsson C, Kindblom JM, et al. Recent MMR vaccination in health care workers and Covid-19: A test negative case-control study. Vaccine 2021;39:4414-8. https://doi.org/10.1016/j.vaccine.2021.06.045.

[98] Gold JE, Baumgarti WH, Okyay RA, Licht WE, Fidel PLJ, Noverr MC, et al. Analysis of Measles-Mumps-Rubella (MMR) Titers of Recovered COVID-19 Patients. MB 2020;11:e02628-20.

https://doi.org/10.1128/mBio.02628-20.

[99] Yengil E, Onlen Y, Ozer C, Hambolat M, Ozdogan M. Effectiveness of booster measlesmumps-rubella vaccination in lower covid-19 infection rates: A retrospective cohort study in turkish adults. Int J Gen Med 2021;14:1757-62. https://doi.org/10.2147/IJGM.S309022.

[100] Mysore V, Cullere X, Settles ML, Ji X, Kattan MW, Desjardins M, et al. Protective heterologous $\mathrm{T}$ cell immunity in COVID-19 induced by the trivalent Measles-Mumps-Rubella and TetanusDiptheria-Pertussis vaccine antigens. Med 2021. https://doi.org/10.1016/j.medj.2021.08.004.

[101] Onwude J, Sokunbi D. Worldwide Childhood Mortality from Covid-19. Ann Pediatr 2021;4:1069.

[102] Ashford JW, Gold JE, Huenergardt MJA, Katz RBA, Strand SE, Bolanos J, et al. MMR Vaccination: A Potential Strategy to Reduce Severity and Mortality of COVID-19 Illness. Am J Med 2021;134:153-5. https://doi.org/10.1016/j.amjmed.2020.10.003.

[103] Larenas-Linnemann DE, Rodríguez-Monroy F. Thirty-six COVID-19 cases preventively vaccinated with mumps-measles-rubella vaccine: All mild course. Allergy 2021;76:910-4. https://doi.org/10.1111/all.14584.

[104] Aspatwar A, Gong W, Wang S, Wu X, Parkkila S. Tuberculosis vaccine BCG: the magical effect of the old vaccine in the fight against the COVID19 pandemic. Int Rev Immunol 2021;0:1-14. https://doi.org/10.1080/08830185.2021.1922685.

[105] Tomita Y, Sato R, Ikeda T, Sakagami T. BCG vaccine may generate cross-reactive $T$ cells against SARS-CoV-2: In silico analyses and a hypothesis. Vaccine 2020;38:6352-6. https://doi.org/10.1016/j.vaccine.2020.08.045.

[106] Nuovo G, Tili E, Suster D, Matys E, Hupp L, Magro C. Strong homology between SARS-CoV2 envelope protein and a Mycobacterium sp. antigen allows rapid diagnosis of Mycobacterial infections and may provide specific anti-SARSCoV-2 immunity via the BCG vaccine. Ann Diagn Pathol 2020;48:151600. https://doi.org/10.1016/j.anndiagpath.2020.15160 0.

[107] Gong W, Aspatwar A, Wang S, Parkkila S, Wu X. COVID-19 pandemic: SARS-CoV-2 specific vaccines and challenges, protection via BCG trained immunity, and clinical trials. Expert Rev Vaccines 2021;20:857-80. https://doi.org/10.1080/14760584.2021.1938550.

[108] Eggenhuizen PJ, Ng BH, Chang J, Fell AL, Cheong RMY, Wong WY, et al. BCG Vaccine Derived Peptides Induce SARS-CoV-2 T Cell Cross-Reactivity. Front Immunol 2021;12:692729. https://doi.org/10.3389/fimmu.2021.692729.

[109] Arlehamn CSL, Sette A, Peters B. Lack of evidence for $\mathrm{BCG}$ vaccine protection from severe COVID-19. Proc Natl Acad Sci U S A 2020;117:25203-4. https://doi.org/10.1073/pnas.2016733117.

[110] Patella V, Delfino G, Bruzzese D, Giuliano A, Sanduzzi A. The bacillus Calmette-Guérin vaccination allows the innate immune system to provide protection from severe COVID-19 infection. Proc Natl Acad Sci U S A 2020;117:25205-6. https://doi.org/10.1073/pnas.2015234117.

[111] Nomura S, Eguchi A, Yoneoka D, Kawashima T, Tanoue Y, Murakami M, et al. Reasons for being 
unsure or unwilling regarding intention to take COVID-19 vaccine among Japanese people: A large cross-sectional national survey. Lancet Reg Heal - West Pacific 2021;14:100223. https://doi.org/10.1016/j.lanwpc.2021.100223.

[112] Pépin J, Labbé AC, Carignan A, Parent ME, Yu J, Grenier $\mathrm{C}$, et al. Does BCG provide long-term protection against SARS-CoV-2 infection? A case-control study in Quebec, Canada. Vaccine 2021. https://doi.org/10.1016/j.vaccine.2021.08.019.

[113] Amirlak lradj, Haddad R, Hardy JD, Khaled NS, Chung MH, Amirlak B. Effectiveness of booster BCG vaccination in preventing Covid-19 infection. Hum Vaccines Immunother 2021;00:13.

https://doi.org/10.1080/21645515.2021.1956228.

[114] Wiwanitkit V. COVID-19 death and BCG vaccination. Tuberc Respir Dis (Seoul) 2021;84:84.

https://doi.org/10.4046/TRD.2020.0115.

[115] Sarfraz Z, Sarfraz A, Pandav K, Singh Makkar S, Hasan Siddiqui S, Patel G, et al. Variances in BCG protection against COVID-19 mortality: A global assessment. J Clin Tuberc Other Mycobact Dis 2021;24:100249. https://doi.org/10.1016/j.jctube.2021.100249.

[116] Bleier BS, Ramanathan M, Lane AP. COVID-19 Vaccines May Not Prevent Nasal SARS-CoV-2 Infection and Asymptomatic Transmission. Otolaryngol - Head Neck Surg (United States) 2021;164:305-7. https://doi.org/10.1177/0194599820982633.

[117] Subunit S. S Protein-Reactive IgG and Memory B Cell Production after Human SARS-CoV-2 Infection Includes Broad Reactivity to the S2 Subunit. MBio 2020;11:e01991-20. https://doi.org/10.1128/mBio .01991-20.

[118] Shah P, Canziani GA, Carter EP, Chaiken I. The Case for S2: The Potential Benefits of the S2 Subunit of the SARS-CoV-2 Spike Protein as an Immunogen in Fighting the COVID-19 Pandemic. Front Immunol 2021;12:1-7. https://doi.org/10.3389/fimmu.2021.637651.

[119] Wadman M. SARS-CoV-2 infection confers greater immunity than shots. Science (80- ) 2021;373:1067-8. https://doi.org/10.1126/science.abm1207.

[120] Fröberg J, Diavatopoulos DA. Mucosal immunity to severe acute respiratory syndrome coronavirus 2 infection. Curr Opin Infect Dis 2021;34:181-6. https://doi.org/10.1097/QCO.0000000000000724.

[121] Amanat F, Thapa M, Lei T, Ahmed SMS, Adelsberg DC, Carreño JM, et al. SARS-CoV-2 mRNA vaccination induces functionally diverse antibodies to NTD, RBD, and S2. Cell 2021;184:3936-3948.e10. https://doi.org/10.1016/j.cell.2021.06.005.

[122] Sadarangani M, Marchant A, Kollmann TR. Immunological mechanisms of vaccine-induced protection against COVID-19 in humans. Nat Rev Immunol

2021;21:475-84. https://doi.org/10.1038/s41577-021-00578-z.

[123] Stephenson E, Reynolds G, Botting RA, CaleroNieto FJ, Morgan MD, Tuong ZK, et al. Singlecell multi-omics analysis of the immune response in COVID-19. Nat Med 2021;27:904-16. https://doi.org/10.1038/s41591-021-01329-2.

[124] Byazrova M, Yusubalieva G, Spiridonova A, Efimov G, Mazurov D, Baranov K, et al. Pattern of circulating SARS-CoV-2-specific antibodysecreting and memory B-cell generation in patients with acute COVID-19. Clin Transl Immunol 2021;10:1-16. https://doi.org/10.1002/cti2.1245.

[125] Semmler G, Traugott T, Graninger M, Hoepler W, Seitz T, Kelani H, et al. Antibody Kinetics in Acute SARS-CoV-2 Infection by a Microarray and Twelve Other Immunoassays 2021.

[126] Fraley E, Lemaster C, Banerjee D, Khanal S, Selvarangan R, Bradley T. Cross-reactive antibody immunity against SARS-CoV-2 in children and adults. Cell Mol Immunol 2021;18:1826 - 1828 . https://doi.org/10.1038/s41423-021-00700-0.

[127] Kumar NP, Padmapriyadarsini C, Rajamanickam A, Marinaik SB, Nancy A, Padmanaban S, et al. Effect of BCG vaccination on proinflammatory responses in elderly individuals. Sci Adv 2021;7. https://doi.org/10.1126/sciadv.abg7181.

[128] Marakasova E, Baranova A. MMR vaccine and COVID-19: Measles protein homology may contribute to cross-reactivity or to complement activation protection. MBio 2021;12:e03447-20. https://doi.org/10.1128/mBio.03447-20.

[129] Mysore V, Cullere X, Settles ML, Ji X, Kattan MW, Desjardins M, et al. Protective heterologous T cell immunity in COVID-19 induced by the trivalent MMR and Tdap vaccine antigens. Med 2021;2:1050-1071.e7. https://doi.org/10.1016/j.medj.2021.08.004. 